\title{
FACTORS FOR THE ECONOMIC MARGINALIZATION OF THE NORTHWESTERN STATISTICAL REGION AND TOOLS FOR ITS OVERCOMING
}

\author{
Dimitar Dimitrov ${ }^{* 1}$ \\ *Sofia University "St. Kliment Ohridski"
}

\begin{abstract}
The Northwestern statistics region is the most backward one in socialeconomic sense in the whole European Union. Its territory is in a process of accelerated depopulation. Its demographic structure is characterized by an inverted age structure of the population. Deteriorated are also the quality and quantity parameters of the factor workforce.

The prevailing part of the municipalities in the region have high rate of unemployment. The infrastructure on its territory is in very bad technical conditions and with low level of functional interconnection. The quality of life of the population as a result of these factors continuously deteriorates. All these unfavorable processes and problems deprive the region from potential for a future social-economic development.

At the same time, this is the Bulgarian region which is geographically closer to the "heartland" of the EU. The relative advantages arising from its geographic position and the implementation of certain policies can become factors for the economic growth of this region. In order to generate positive territorial synergy, a profound analysis of the factors that led to this situation should be carried out.

The article analyses also the factors that led to the economic marginalization of the Northwestern statistics region and it justifies some policies and methods that can lead to its overcome.
\end{abstract}

Key words: regional development, regional policy, depressive regions, local selfgovernment, transborder cooperation.

\footnotetext{
${ }^{1}$ Correspondence to: dimitar@gea.uni-sofia.bg
} 
The Northwest statistical region is characterized by a specific location and characteristics, both within the national geographical territory and also in thee overall economic and cultural territory of the EU. It is one of the most problematic socio-economic EU regions, characterized by the lowest social standards of its population and an accelerated depopulation of most of its territory, outdated infrastructure and housing in the settlements (see Deđanski et al., 2014; Ђорђевић и др., 2012; Шабић и Михаилов, 2007). The destroyed industrial base of the fixed assets further deprives the region of future perspectives for development.

The territorial extent of the region according to the Regional Development Act (RDA) from 2008 includes the districts of Vidin, Montana, Vratsa, Pleven and Lovech (Figure 1.). Regarding the territorial extent of the Northwestern statistical region, the socio-economic region and the geographical region, there are certain differences. The definition Northwestern Bulgaria as according to the common idea includes the districts of Vidin, Montana, Vratsa. Its territory overlaps with the territory of integral social economic region. In almost all scientific integrated socio-economic zonings of Bulgaria: Beshkov, 1934, Geography of Bulgaria, Bulgarian Academy of Sciences, 1961, Geography of Bulgaria, Bulgarian Academy of Sciences, 1989 , etc. the area is perceived in these borders and territorial extent. The region is in this territorial extent also in the Regional Development Act dated in 1999 and 2004. The amendment of the RDA dated 2008 of the territorial borders of the region, by including the regions of Pleven and Lovech, is done for formal statistical reasons and in response of the requirements and criteria of Eurostat for the inclusion of the region in the level NUTS-2 level for which a thresholds for the population of 800000 inhabitants is required. Due to extremely unfavorable demographic processes and its accelerated depopulation the region does not meet these requirements. The mechanical inclusion of Pleven and Lovech districts to it is not based on any geographic and socio-economic logic for the following reasons:

- In all integrated socio-economic divisions of the country these two areas objectively made part of the North-Central socio-economic region respectively to Vitsko-Osamski socio-economic sub-region. (Geography of Bulgaria, BAS, 1989)

- The economic ties of the two areas always had two main vectors: the Southwestern socio-economic area primarily the city of Sofia and with significantly less intensity towards Veliko Tarnovo and Gabrovo (Yantrenski socio-economic sub-region and the North Central social-economic area)/ 
- The economic relations of the two areas to the west are limited and incidental, and they have no influence in terms of the economic consolidation of the Northwestern statistical region.

- In terms of the natural and geographical division of the country, the territories of the two areas are assigned to middle parts of the respective natural geographic units (Central Danubian Plain, Central Fore Balkan and Stara Planina).

The merely mechanical integration of the two areas (Pleven and Lovech) to the Northwestern statistical region is not rational in terms of regional planning and the development of their territory. Another issue is that as a result of the irrational wholesome social-economic and regional policy implemented in the country over the past 25 years, the socio-economic and demographic characteristics of the two areas are becoming similar to the three "classical" areas of Northwestern Bulgaria (Vidin, Montana, Vratsa). Regardless of the obstructions expressed in terms of the borders and the territorial extent of the Northwestern statistical region, the present article examines it as a compact territory.

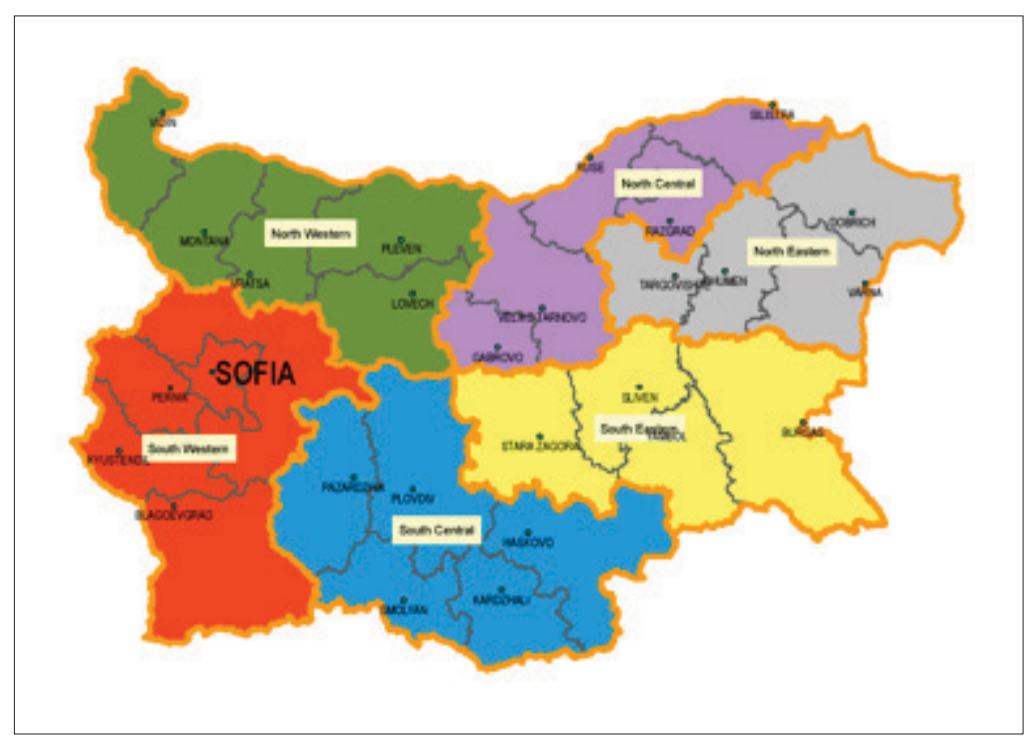

Figure 1 - Territorial scope of the statistical regions of Bulgaria - Regional Development Act, 2008

Source: http://www.nsi.bg/nrnm/ 
As a whole the Northwest region is statistically with the worst demographic, socio-economic and infrastructure problems in the country. Vidin district became the first among the 28 districts in the country, whose population fell below the threshold-values of 100000 inhabitants. Its population in 2014 was 93000 people (National Statistical Institute-NSI). Close to it, though relatively more favorable demographic characteristics have the areas of Montana and Vratsa. The district of Lovech has the highest level of deterioration of the investment potential among the 28 districts in the country (Institute for Market Economy-IME, 2014). In the last 25 years, it has reduced its population from approximately 240000 p. in 1990 to 129000 in 2015 (NSI). These negative trends are observed also in the internal demographic structure of the region. Structure cities in terms of the urban network of the region such as Lovech and Troyan sharply reduced their population. In 25 years the Lovech region reduced its population from approximately 54000 people (in 1990) to 18000 people (in 2015) and Troyan from 26000 (in 1990) to 13000 people (in 2015). The district of Pleven regardless of the mechanical transfer in 2001 of the municipality of Knezha from the Vratsa district (33000 p.) for the period 2001-2011 has reduced its population by approximately 40000 people. The town of Pleven itself for the last 25 years has reduced its population from 130000 to 80000 people and it is increasingly losing its status as a major economic center in the Central Danubian Plain. Severe are the demographic processes in the settlements of lower rank in the region. In the southern part, it is observed the formation of a depressive demographic area formed in the region of Stara Planina and the Fore Balkan. Its territorial scope is expanding more and more to the north of the Danube Plain.

The negative demographic trends in the region are catalyzed by negative trends in its economic structure: the collapse of its industrial base, marginalization of arable land, amortization of the infrastructure/transport, social, technical and other one/and of the housing.

The negative characteristics of the region additionally detorriare due to increasingly obsolete transport infrastructure and lack of significant investments in its rehabilitation and development. The delay in infrastructure development of the highway of "Hemus" further negatively impacts the business processes in the southeastern part of the region. Similar negative impact has the project for a high speed railway line: Vidin - Montana - Vratsa-Mezdra-Sofia. This transport project is frozen for an indefinite period of time due to lack of funding. 
The economic and infrastructural marginalization of the Northwestern statistical region is a result of the continued impact of a complex of factors. The ones with biggest impact are:

- geopolitical factors

The region is "wedged" deep to the territory of Romania and Serbia (past of former Yugoslavia). Due to decades of negative influences in the bilateral relations between the former Yugoslavia and later Serbia and Bulgaria, the western border of the region that coincides partially with the western state border is economically underdeveloped. Alongside the border only two checkpoints operate: Bregovo-Negotin and Kula -Zaychar (checkpoint Vrashka Chuka). There are two other potential border checkpoints: at the village of Salad Pass - the Kada Boaz lane and Chiprovtzi lane. In perspective, and especially after the full EU membership of Serbia, it is appropriate that those cross-border projects are realized. This will gradually lead to economic activation of the crossborder areas alongside the common border and will expand hinterland of the formation of traffic flow over the bridge "New Europe."

Nevertheless the relatively good bilateral political relation between Bulgaria and Romania during the socialism the economic degree of use of the north (Danube) border is also weak. For nearly 60 years only the ferry of Vidin-Calafat has operated. This highly obstacled both the passenger and freight traffic through the border and it was an obstacle to the realization of crossborder projects. With the implementation of the three cross-border transport projects along the northern border of the region: the bridge "New Europe" - 15:06. 2013 at Vidin-Calafat and the ferries of Oryahovo-Bechet-1994 and Nikopol-Turnu Magurele-2010, the economic situation has improved significantly. The implementation of these projects started only when the membership perspective in the EU for both countries has been confirmed.

- social-economic factors

They have biggest weight for the economic marginalization of the northwestern statistical region. Among the factors with biggest impact is the process of industrialization in the region. In the territory of the "authentic" Northwest Bulgaria (the districts of of Vidin, Montana, Vratsa) this process takes place much later compared to the other regions in the country- only in the 70s of XX-th century. The main structural enterprises come into operation during this period: NPP "Kozloduy"-1974, the "Vidachim", "Himko" -Vratsa, the trucks factory and the sugar factory in Lom, the battery factory "Monbat", the factory for floor ceramics in Montana etc. For this reason, in 
terms of realization of the production, these companies were market- oriented towards the former Comecon countries and in the first place to the markets of the former Soviet Union. The collapse of these political and economic structures due to geopolitical reasons is the main reason for the collapse of industry of these three districts.

In the other two districs the situation is much different. Pleven and Lovech during the period of planning and centralized economy were characterized by a high degree of industrialization and economic development. Some of them developed industries which were structurally defining within the national economic sectors of the electrical industry, the wood production, the chemical, pharmaceutical and chemical industry, the electrical industry, etc. With regard to agriculture and agrobusiness, the district of Pleven is one of leading producers of grain (barley, wheat, corn). The district of Lovech in the period until 1990 was a leading productor of plums, giving $40 \%$ of the national production of this culture. Both areas had a high degree of specialization in animal husbandry. High level of development was reached both in the light and food industries. The economic downturn in the districts was caused in the period since 1990 onwards, due to the result of the policy of total de-industrialization of the country and the wrong general philosophy of social and economic development over the past quarter of century in Bulgaria. For this reason their business activazation could not be achieved out of the context of radical change in the philosophy and in the economic policies.

- demographic factors

The impact of this factor logically should be considered in parallel with the social -economic factor. Moreover, it is necessary to make a clear distinction: the territory of Bulgaria with the traditional Northwest regions Vidin, Montana, Vratsa and Pleven and Lovech districs, considered as separate sub-regions. As a result of the later industrialization of the first three areas during the period between 1944-1970, intense migration flows have been observed from the Northwest of Bulgaria to Sofia. With much lower intensity were they during the period: 1970-1990. In the period after 1990 these migration tendencies already have the characteristics of a kind of "migration boom", leading to a total depopulation of the area. No other region in the country has been depopulated in terms of labor resources in such a large degree as Northwestern Bulgaria. The demographic expansion of Sofia in the $60 \mathrm{~s}$ of XX-th century is largely due to these waves of migration. The migration flows from Pleven and Lovech districts of the capital city-intensified in the period after 1990 due to their de-industrialization and intensified over 
the past decade. These labor migration flows strongly deteriorated quantitative and especially quality specification factor workforce in throughout the Northwest statistical region. From its territory working-age people with higher education and vocational training have been migrating. This process deprives the region of future potential for socio-economic development, reducing significantly its investment attractiveness.

- Natural and geographical factor

The geographical characteristics of the Northwest region are more catalyzing than limiting factor in terms of its social-economic and regional development.

The plain and plain-hilly nature of the terrain in the northern and central parts of its territory are very important prerequisites for achieving a relatively proportional development of transport infrastructure in its territory. This model will greatly reflect on increasing the sustainability of the urban network in it. Both factors are decisive for the rational utilization of its overall potential.

The region has some of the most fertile soils throughout the country: the Danube alluvial lowlands (Vidin Valley, Lomska and Oryahovska Zlatii, Kozloduy, Nikopol and Belene lowlands). They are occupied by marsh and alluvial soils with high humus content and are suitable for potential development of intensive farming. The central parts of the area are occupied by the Western Danubian Plain. In this part, it is the flat, which makes it suitable for the development of intensive agriculture and agrobusiness, through the application of modern and high-performance production methods. The territorial proximity of the region to the city of Sofia combined with reasonable economic policy for the realization of the potential of agricultural production in these markets could turn the region into a major supplier for the capital city with such production for fresh consumption.

The mountain chain of Stara Planina in the south consists predominantly of ridges of height of just over 2000 meters. This creates a certain obstacle for the development of the linear transport infrastructure to the south - towards Sofia and Southern Bulgaria. These natural and geographical characteristics of its southern territories require the adoption of specific planning and technical solutions to streamline the transport infrastructure and link the region with Sofia and South Bulgaria as a whole.

The region's reserves of minerals are limited in quantity and do not constitute a significant raw-resource base for its prospective social-economic development. These resources are the deposits of iron ore in the villages 
of Martinovo, Chiprovo in Montana and Chiflik in the Lovech region. Although the iron content in the ore is relatively high (43\%), the reserves are limited (under 1 million tons) which makes them non significant for future exploitation in the current economic situation in the country. Ores of nonferrous metals (copper in the Vratsa mountain and lead-zinc ore in Martinovo, Montana) are also limited in quantity, so that both fields are without perspectuve for future industrial mining. There are limited deposits of gold in the sediments of the upper part of Ogosta the river and its affluents. However, these reserves do not consist an essential resource for the development of a promising gold mining in the region.

The region is one of the few in the whole country with proved deposits of natural gas and oil. The large number of localities of natural gas throughout its territory (Chiren , Kriva Bara, Hajredin, Mizia and Oryahovo, Bhutan- Vratsa, Gigen, Gulyantsi, Bohot, Dolni Dubnik, Telish-Pleven; Devetaki-Lovech) have a limited amount of these reserves which are not serious potential for development of gas extraction in the region. More substantial natural gas reserves have been found in 2007 at the gas field of Deventsi, the municipality of Cherven Briag. The Industrial natural gas reserves there are estimated at 12 bln. cubic meters of gas. In this field the gas is of high quality, low impurity content and good technical parameters for extraction. Extraction is still not implemented because of the moratorium on shale gas extraction in the country, which affects also the newly discovered deposits of conventional natural gas. Deposits of oil in the area around Pleven (Dolni Dubnik, Telish, Bohot) have been exhausted in the early 80-ies of the XX-th century, which is the reason for the the elimination of the activity of our third oil refinery "Plama" Pleven.

The region has some stocks of non-metalliferous minerals which in case of rational involvement in economic turnover could become a sustainable factor for an economic growth. Such resources are the stocks of plaster. They are of significant quantity and are concentrated in a few localities: the villages of Koshava and Slanotran, Novo Selo and the town og Belogradchik, Vidin district; in Oryahovo and in Mizia, Vratsa region. Industrially important are the deposits in Koshava and Novo Selo, Vidin. There are significant reserves of marble breccia at the village of Chelyustitsa, Montana. Of interest for the industrial production are the stocks of refractory clays in the region of Bukovlak and Opanets, Pleven. There are also standard clays in a number of localities in the region. Industrially these reserves are significant, so they aer promising raw-resource base for development of sustainable industry with diverse production of construction materials. The deposit of clay in Klisuritsa, Montana is promising raw-resource base for the plant 
floor ceramics in Montana. The deposits of limestone and marl in Beli Izvor (Vratsa) and Biala Voda (Pleven) are promising raw material base for the development of the cement industry and lime. Deposits of limestone facing the villages of Gorna and Dolna Kremena, Varbeshnitsa and Tsarevets are significant and promising for extraction. With possible ndustrial importance are the deposits of marble and granite in Berkovska Mountain and in the village of Chelyustitsa (Chiprovo). The aggregate materials obtained along the Danube River and the lower affleunts of the rivers in the region are significant and promising raw-resource base for the development of construction industry and construction materials in the region.

- ecological factors

They areessential resource for sustainable economic development of the region. Particular areas of its territory are ecologically preserved because of his weak economic development. These factors in case of their rational use could become perspectives for the acceleration of its economic growth. The most compact such areas are located in the southern part of the region covered by the Western and Central Stara Planina. On their territory there are important biosphere reserves of national and global importance. On the territory of the region of Lovech , a significant part of the national park "Central Balkan" is situated. There are also protected natural sites with high attractive value. Biosphere reserves: "North Djendem", "Stenetno", "Tsarichina", "Boatin", "Chuprene" keep important natural sites of the national and world natural biosphere wealth. In the northern part of the region is located biospheric reserve "Persina" which is the habitat of rare bird species and marsh plants and animals. They all represent significant potential for the development of nature orientated tourism. The relatively high range (over $2000 \mathrm{~m}$.) of the bigger part of the southern boundary of the area along the central and western Stara Planina offers good conditions for the development of ski tourism and winter recreational tourism. In conjunction with the territorial proximity of these areas to the capital and the favorable transportation and geographical position this tourist destination could become another alternative for the development of the of ski tourism in Bulgaria as a whole. Most suitable for its development are locations of the hut "Pleven", "Beklemeto", "Petrokhan" and Berkovitza.

Regardless of the extremely unfavorable demographic and social-economic trends in the statistical Northwestern region, considered the new geopolitical conditions, the region could overcome these severe problems in its development. However, this requires a radical change in the ongoing socialeconomic and regional policy. This change should be in two main directions: 
- the inclusion of its whole territory in the preferential regional policy;

- generation of regional synergy as a result of the combination of the potential impacts of existing in the region factors with a positive impact;

In terms of preferential regional policy, it needs to be spread throughout its whole territory. This is related to the implementation of measures for relatively long period of time:10-15 years in the following aspects:

1. The exemption from capital gains tax of the physical and legal persons in case of reinvestment of these gains the region. This measure could largely contribute for the status of its territory as free economic zone. Given the interest of some potential foreign investors in terms of realization of transport infrastructure and economic projects (port Lom), the high peed railway line Vidin-Sofia , the nuclear electric plant of "Kozloduy" and others could largely activate the business on its territory.

2. The implementation of economic policy aimed at the recovery of the structurally important economic sectors of the region. This is a completely realistic economic outlook, provided that the advantages of the region in terms of its transport, geographical and geopolitical situation are used.

3. Conducting long-term economic policy aimed at creating a regional network of micro, small and medium enterprises, based on the utilization of regional and local resources in the region. It is reasonable that they are based on: the use of still present manufacturing traditions of the people in the traditional regional industries of the light and food industries (vegetable and food conservation producion), the construction of mini territorial manufacturing cycles in the agriculture and agrobusiness for the production of biologically clean agricultural products and foods. This is related to the potential for rapid and guaranteed realization of its production in the capital and other big consumer market centers in the country and it twill contribute to a great extent for the activation of the business throughout its territory.

Generating positive regional synergy in the Northwest region could be achieved by combining the impact of the following factors:

1. The change in the geopolitical situation of the region.

For the past quarter of century, it has undergone considerable changes. For the first time in the modern economic history of the region, there are 
real prerequisites for a permanent overcoming the negative effects in the bilateral political relations between Bulgaria on one hand and Serbia, and to a certain extent and Romania on the other. These relations have reflected negatively for a long time on the regional transboundary cooperation and implementation of important infrastructure projects. The membership of Bulgaria and Romania in the EU and real prospects for such membership for Serbia in the near future radically changes its geopolitical position. The inclusion of the territory of the region within the pan-European region "Lower Danube" creates potential conditions for the realization of major infrastructure and economic projects financed by the EU structural funds and gives the possibility for implementation of strategies and programs for regional development of the union.

2. The active participation of the region in the implementation of the "Danube Strategy" of the EU.

This could be of importance not only for the Danube river communities, but also for the whole for its territory. Its northern (Danube) border occupies $65 \%$ of our entire Danube border. The funds provided for its implementation are significant-93 billion euros for the States of the whole area of the river. If the municipalities are active in proposing projects within this Strategy they could improve the parameters of their development in the following areas: 1. rehabilitation and development of the transport infrastructure in the area; 2. establishing a network of small medium enterprises for the utilization of local resources; 3 . The implementation of projects and educational programs to enhance the educational and professional qualification level of the population; 4 . implementation of projects to improve the environmental performance of the living environment.

3. The comparative advantages of the region, resulting from its favorable transport and geographical location

The dynamics of geopolitical factors over nearly three decades led to dynamics and presumption in transport and geographical situation of the region. This is the region of the national territory, which has the largest territorial proximity with the EU hardland. This comparative advantage is rationable to be used as a factor for economic activation, through the implementation of transport infrastructure projects for the territorial development. These projects should not be chaotic and occasional, only for the absorption of certain financial resources and should be subject to certain logic in the following areas: 
a) implementation of transport infrastructure projects related to the continuation of the process of opening up of the national geographical space to Western and Central Europe, through the borders of the region. It is thus essential infrastructure development and modernization of the Danube ports and especially the port of Lom. Infrastructure modernization of the existing links and development of new cross-border ones with Serbia in Western Stara Planina;

b) the development of intra-regional linear transport infrastructure to connect the Danube ports with the envisaged cross-border connections from one side, and linking them with infrastructure elements along the $\mathrm{IV}^{\text {th }}$ euro corridor in the region;

c) the delivery of of resources for implementation of transport projects of local importance through which to optimize transport access throughout its territory. The application of this algorithm will allow to valorize the transportat and geographical location and will help to neutralize the negative potential.

4. The use of its territorial proximity to Sofia as a factor in its economic growth.

The territorial proximity of the region to Sofia under the new economic conditions could become a factor for its business activation. The demographic depression of the region and its economic marginalization is to a big extent due to this territorial proximity to Sofia. This factor in the new economic conditions should be used in the following directions:

a) transformation of the region into a major supplier of agricultural production.

Through the implementation of a policy, the region could become the second most important after the Upper Valley to supply the capital with agricultural goods. Important prerequisites for this are the favorable agro-climatic conditions allowing the development of multifunctional agriculture with wide production profile: grain, vegetable ad fruits production, wine, etc. The natural conditions allow the development and full range livestock breeding in the region.

b) conversion of its territory in the second most important tourist destination after Rila and Pirin for short skiing vacations for the residents of Sofia aglomeration. These capabilities will be significantly enhanced after the modernization of the 
transport infrastructure: construction of a tunnel under the highway Petrohan Passage and the overall infrastructural development of the route of IV-European corridor with its main components-speed road way and speed railroad.

5. Inclusion of its natural resources potential as a factor for its business growth.

Despite the fact that the established deposits of minerals on its territory are not significant in quantity, they can become raw material and resource base for the construction of mini-territorial manufacturing cycles, some of which become of structural improtance for the for the respective municipalities and districts. The region has considerable natural-resource potential (forest resources, soil resources, environmental resources and others). Which in case of their reasonable involvement in economic turnover could become resistant factor for its economic growth.

\section{Conclusions}

As a result of the performed factor analysis for the development of Northwestern statistical region the following conclusions can be made:

- The demographic and economic marginalization will continue to worsen if a radical change is not implemented in the regional and comprehensive social-economic policy;

- This policy should be based on the proposed algorithm for involvment of its territory in favorable factors for the economic development;

- Achievement of a sustainable model of regional development in the region could only be achieved with the pursuit of rational complex socio-economic policy

- Generating sustainable regional synergy on the territory could only be achieved in a rational and balanced combination of the analyzed factor influences on its territory.

\section{Reference}

Географията в съвременна България, София, БАН, 1986.

География на България, Физико-географско и социално-икономическо райониране, Том. 3., София, БАН, 1989. 
Ђорђевић, Д., Дабовић, Т., Живак, Н. (2012). Слабост просторног планирања у Србији на примеру планирања просторног развоја пограничне зоне према Бугарској. Гласник Географског друштва Републике Српске, 16, 43-59.

3PP: 1999; 2004; 2005; 2008.

Институт за пазарна икономика, Актуални социално-икономически профили на 28-те области в страната, София, 2014.

Национална стратегия за регионално развитие на Република България за периода 2012-2022 г.

Национална концепщия за пространственно развитие за периода 2013-2025 г.

Областна стратегия за развитие на Област Видин 2014-2020 г.

Областна стратегия за развитие на Област Монтана 2014-2020 г.

Областна стратегия за развитие на Област Враца 2014-2020 г.

Областна стратегия за развитие на Област Плевен 2014-2020 г.

Областна стратегия за развитие на Област Ловеч 2014-2020 г.

Регионален план за развитие на Северозападния регион за периода 2014-2020 г.

Стратегия за развитие на транспортната система на Република България до 2020 г.

Шабић, Д. и Михаилов, В. (2007). Упоредна анализа неких социоекономских показатеља развоја Србије и Бугарске, У Тодоровић, М. (ур.): Први конгрес српских географа, Српско географско друштво, Географски институт САНУ, Географски факултет у Београду, Департман за географију, туризам и хотелијерство - ПМФ у Новом Саду, Београд, 599-607.

Deđanski, V. Živanović, V. Kovjanić, A. (2014). Influence of the construction of hydroelectric plant „Djerdap I“ on the socialgeographic changes in the settlements of the municipality Majdanpek. The third Romanian-BulgarianHungarian-Serbian Conference: Geographical Research and Cross-Border Cooperation within the Lower Basin of the Danube, Srebrno jezero, 2014. 